
permits unrestricted re-use, distribution, and reproduction in any medium, provided the original work is properly cited.

\title{
Erratum
}

\section{Jacobitism, Coastal Policing, and Fiscal-Military \\ Reform in England after the Glorious Revolution, 1689-1702 - ERRATUM}

\section{Hannes Ziegler}

In the above article ${ }^{1}$, an incorrect corresponding email address was listed for author Hannes Ziegler. The correct corresponding email is hannes.ziegler@lmu.de. The publisher apologizes for this error.

\section{Reference}

${ }^{1}$ Ziegler, H. (2021). Jacobitism, Coastal Policing, and Fiscal-Military Reform in England after the Glorious Revolution, 1689-1702. Journal of British Studies, 1-25. doi:10.1017/jbr.2021.113 